NICO BORTOLETTO

University of Teramo, Italy
ALESSANDRO PORROVECCHIO *

University of the Littoral Opal Coast, France

\title{
SOCIAL INCLUSION THROUGH SPORTS A SHORT COMPARISON OF ITALY AND FRANCE
}

\begin{abstract}
The recent flow of immigrants to Italy and France, two countries that are the principal destinations after crossing the Mediterranean Sea, has turned out to be a complex and multidimensional problem to manage. Both France and Italy organised a complex method for welcoming and distributing the migrants around their territory as much as possible, hosting them in structures adapted or created for this purpose.

On the Italian side, two main issues might be identified and analysed: on the one hand the humanitarian emergency of the reception of the migrants, on the other hand, the difficult processes of social integration/inclusion which were put in place. On the French side, these issues are linked to the managing of the risk of radicalisation, in a context in which the memory of the recent terrorist attacks remains vivid.

In dealing with the management of the process of social integration/inclusion, sport has proven to be an important (although controversial) opportunity for social inclusion of young immigrants. Micro participatory action-research has highlighted the potential given by a shared cultural framework, such as that provided by the practice of sport. On the Italian side, these practices have not yet been institutionalised, while on the French side there is a more organic strategy, based on a longer standing tradition of using sport as a means of social inclusion.

Starting from this premise about the situation of the two countries, we will propose a descriptive and theoretical comparison based on some case studies that we consider significant in terms of the French and Italian approach to social inclusion through sports.
\end{abstract}

Keywords: sports, social inclusion, youth, immigration, policies, France, Italy.

\footnotetext{
* Corresponding author: University of the Littoral Opal Coast. EA 7369 - URePSSS - Unité de Recherche Pluridisci-
} plinaire Sport Santé Société, F-59140 Dunkerque, France. E-mail: alessandro.porrovecchio@gmail.com 


\section{Introduction}

Sport attracts European citizens, with a majority of people taking part in sporting activities on a regular basis. It generates important values such as team spirit, solidarity, tolerance and fair play, contributing to personal development and fulfilment. It promotes the active contribution of EU citizens to society and thereby helps to foster active citizenship. The Commission acknowledges the essential role of sport in European society, in particular when it needs to bring itself closer to citizens and to tackle issues that matter directly to them. However, sport is also confronted with new threats and challenges which have emerged in European society, such as commercial pressure, exploitation of young players, doping, racism, violence, corruption and money laundering. (Commission of the European Communities, 2007: 2)

The quoted paragraph is taken from the "White paper on sport" (Commission of the European Communities 2007: 2), and it summarizes briefly a number of trends that characterize the link between sports and society.

The Commission of the European Communities clearly shows the characterization of sport as a cultural phenomenon. Especially through the media, every day sports produce concepts and representations that society embodies to the point where we talk about a progressive "sportivisation of culture": it seems that sport is becoming one of the prevailing frameworks of interpretation of contemporary symbolic practices (Bausinger 2006: 39), an element holding society together (Bausinger 2006: 37), or even an omnipresent pervasive phenomenon (Vinnai 2007).

It is clear that contemporary sports are changing, as far as their practice is concerned, their representation and the way in which they are "used" (see for instance: Höglund, Sundberg, 2008); this phenomenon should be framed within the wider transformation of contemporary societies and culture, in which sports and physical activity are becoming more and more important as an object of study of social sciences - as proven by the increase of sports-based social and health policies. These last phenomena go together with the expansion of sports' demand that is seemingly merging with a sort of democratization of access to sports and physical activities.

The "White paper on sport", should be framed within the context that we have just described. Its priorities are included in the Lisbon Treaty of December 1st 2009, and it encourages Member States to integrate sporting practices into education, public health and social cohesion policies. This means that its aim was to emphasize, in a perspective of social promotion, the aptitude of sports and physical activities to promote values, socialisation and integration. Thus, the long-term objective of the "White paper on sport" can be seen to be enforcing and promoting some beneficial practices to help the development of personal and collective identity, and, in a broader social dimension, to promote active citizenship. 
The importance of sports' values is strongly tied to its importance both as an agent and as an environment of socialisation: sports can provide rules, models, behaviour patterns and directions for the development of a growing awareness of the social context. This is adeptly explained by Kinda Moussa in his PhD thesis (2013), these values were already questioned by Maurice Baquet (1947, p.10) for whom "sport has virtues: but virtues that are taught", which means that - as stated by William Gasparini - "sport can be both a factor of integration and of exclusion" (2004, p.104). This duality in the role of sport is highlighted by many scholars: the sports historian Gilbert Andrieu (2009), for example, likes to plagiarize Maurice Baquet's words by writing "if the sport has virtues they are not taught $[\ldots]$ what we teach through sport is the robotisation of sport" (2009: 194), and a few lines later he wonders whether "when sport is used to channel violence and when we train a prison guard to teach it, doesn't it become an agent of repression?" (2009: 194). This approach isn't so far from the critical perspective proposed in France by Jean-Marie Brohm (i.e. 2006) and in Belgium by Claude Javeau (2015), and is a kind of theorization that has not organically developed in the Italian sociology of sports.

Starting from these premises, and going into the detail of our paper, sports practice is subject to endless debates about whether it really carries the virtues of integration, socialization, strengthening of social bonds, or conversely, if it generates violence and aggressiveness, or even if it causes identity withdrawal. On the other hand, physical activities and sports activities for people who have withdrawn from society (delinquents, drug addicts, etc.) are often favourable for personal development (Le Breton 2003; Coakley 2011; Ghildiyal 2015). But if they bring no pleasure to those for whom they are designed, they are in vain, they contribute to the loss of faith in the agents (coaches, social workers and so on) or the institution, they can even be counterproductive for the people involved in the integration or socialisation programs. According to David Le Breton (2003), the austerity of an approach trying to "help" the Other from the perspective of a renewed puritan ethics contains a promise of failure. The same can be said of the utilitarian aim that confuses social engineering with the real conditions of existence, by obscuring the margin of autonomy of the actors, and the ambivalence of the anthropos, that is of the human as a social and symbolical being, with its own criticalities and its potentialities. (Le Breton 2003)

By examining these ambivalences, our paper will analyse the main policies and experiences of social integration/inclusion through sports put in place in Italy and France. In particular, we will try to shed light on the elements of similarity and/or divergence between the two countries, to propose some possible comprehensive and interpretative frameworks to understand the two (different) contexts, taking into account all the critical aspects rooted in both the "integration" and/or "inclusion" approaches. For these reasons, we find this topic very important since the selected cases of study - Italy and France - as highlighted by Bergamaschi (2013) "are two contexts that summarize the fracture existing in Europe on the theme of immigration", both as far as the temporal dimension is 
concerned, since immigration is a recent phenomenon for Italy and a historically rooted reality in France. Each country exhibits a political dimension, which sees a different level of interference by the state in terms of the phenomenon. Politicians have a far greater influence in Italy than in France.

Using this premise as a starting point for our methodology our paper will propose a descriptive and speculative comparison based on some case studies that we consider significant for the French and Italian approaches to social inclusion through sports. The method that we chose was basically descriptive, given the multiformity of the chosen approaches, not only by the two states but also by the local collectivities hosting the immigrants. The cases considered were chosen employing the supposition that processes of social connection within and between groups, within the community (Ager, Strang, 2008) could be a good start for enlarging the base of the integration concept. In this paper we do not provide statistical comparisons on different levels of supposed integration. For the reasons indicated above, we will describe differing national approaches and, using some theoretical elements, we will shortly discuss the policy indications garnered from the considered cases.

\section{Immigration in Italy and France: some basis of understanding}

Immigration represents one of the most prominent economic and political issues in Europe as well as in most of the developed world. More than 247 million people, or 3.4 per cent of the world population, live outside their countries of birth. Although the number of international migrants rose from 175 million in 2000 to more than 247 million in 2013 and surpassed 251 million in 2015, the proportion of migrants has remained just above three per cent (of world population) for the last fifteen years. (Migration and Remittances Factbook 2016)

The Southern Mediterranean Sea, after the tragic 2011 Libyan first civil war, has become one of the most congested routes for trying to reach Europe and, in general, the Western countries. This situation has led to an over-exposure of the nations overlooking the basin, which represented the natural destinations of the sea crossing.

In this sense, two of the most implicated countries are Italy and France. The former, mainly, due to historical reasons and the presence of two small islands, Pantelleria - situated only $60 \mathrm{~km}$ west of the Tunisian coast - and Lampedusa, about $230 \mathrm{~km}$ north of the Libyan coast, has traditionally been the ending point of long migration routes from the whole of Africa. 
The table 1 shows the trend of illegal imigrants landings on the southern coast of Italy:

\begin{tabular}{|c|c|}
\hline 2014 & 171.71 \\
\hline 2015 & 154.719 \\
\hline 2016 & 181.436 \\
\hline 2017 & 119.369 \\
\hline
\end{tabular}

Source: data obtained from the Italian Ministry of the Interior website.

Due to a contested agreement with the Libyan authority, from July 2017 onwards, landing have been significantly reduced and, for 2018, around 58,000 new illegal immigrants are overall expected to land on Italian territory from across the Mediterranean Sea.

Most of these people coming from Africa are, basically, economic migrants: as we will notice most of them apply for refugee status but the majority of the applications (93\% on average during these last 3 years - Interior Min. Database) were rejected by the prefecture commissions. We must stress that the Italian Republic has accorded on average a $25 \%$ of humanitarian stay permission and $9 \%$ of subsidiary permission (when the immigrant is in personal danger if returned to the home country). In 2017, for instance, in Italy migrants applying for "right to stay" permits mainly come (and applying for refugee status) from these Nations:

The table 2 shows the amount of immigrants applying for "right to stay" permits in Italy per country of origin:

\begin{tabular}{|c|c|c|}
\hline Country & $\mathrm{n}$ & $\%$ \\
\hline Nigeria & 25.964 & $20,0 \%$ \\
\hline Bangladesh & 12.731 & $9,8 \%$ \\
\hline Pakistan & 9.728 & $7,5 \%$ \\
\hline Gambia & 9.085 & $7,0 \%$ \\
\hline Senegal & 8.680 & $6,7 \%$ \\
\hline Ivory Coast & 8.374 & $6,4 \%$ \\
\hline Guinea & 7.777 & $6,0 \%$ \\
\hline Mali & 7.757 & $6,0 \%$ \\
\hline Ghana & 5.575 & $4,3 \%$ \\
\hline Eritrea & 4.979 & $3,8 \%$ \\
\hline Ukraine & 2.862 & $2,2 \%$ \\
\hline Syria & 2.270 & $1,7 \%$ \\
\hline Somalia & 2.055 & $1,6 \%$ \\
\hline Cameroon & 2.034 & $1,6 \%$ \\
\hline Morocco & 1.852 & $1,4 \%$ \\
\hline Iraq & 1.661 & $1,3 \%$ \\
\hline Others & 16.497 & $12.7 \%$ \\
\hline
\end{tabular}

Source: data obtained from the Italian Ministry of the Interior website. 
The relevant number of illegal immigrants present in the Italian territory is closely linked to the general geopolitical situation of the African continent and, equally, to the possibility of finding - in relatively short periods of time - a job, frequently in the black labour market.

Eventually, most of these people will remain in Italy and about 15\% are formally re-allocated in Europe ${ }^{2}$ (on the bases of the Frontex rules); a part of these people will try to join autonomous relatives or communities, mostly located in Northern Europe, in France first of all (as the recent tensions between Italian and French customs officers in Bardonecchia demonstrate ${ }^{3}$ ), Sweden, Great Britain and Germany.

As for France, 12 million immigrants or descendants of immigrants live there. Some of them live in disadvantaged neighbourhoods that are hotbeds for economic and social difficulties: failure at school, high unemployment, delinquency and so on. Racism, housing and hiring discrimination reinforce these inequalities.

Trying to analyse this situation and quantify it is rather complicated, given the difficulty or impossibility of collecting data on the ethnic origin of people: in France, in the first point of Article 8 of the law of January 6th, 1978 (formerly article 31), modified by the law $n^{\circ} 2016-1321$ of the October 7, 2016, we can read that "It is forbidden to collect or process personal data that directly or indirectly reveal racial or ethnic origin, political, philosophical or religious opinions, or trade union membership of the persons, or relating to their health or sexual life". In addition, the CNIL (Commission Nationale de l'Informatique et des Libertés - National Commission on Informatics and Liberties, an independent French administrative regulatory institution whose mission is to ensure that data privacy law is applied to the collection, storage, and use of personal data), considers that treatment operated upon the basis of the consonance of the name or the surname of a person or certain multi-criteria treatments should be related to this same Law.

And yet, some generic data is still collected, at a national level. The data published in January 2018 by the French Ministry of the Interior shows an increase in the number of requests for of residence permits in 2017 compared to 2016 (262.000 vs. 230.353 , that is $+13.7 \%$ ). In particular, there is an important increase of residence permits for humanitarian reasons ( 40.305 vs. 29.862, $+35 \%)^{4}$. This data is clearly the tip of the iceberg concerning quantitative trends that are difficult to estimate, but that surely underlines an worsening of the international humanitarian crisis. ${ }^{5}$ When questioned in November 2017 by the

\footnotetext{
${ }^{2} \mathrm{http} / /$ www.interno.gov.it/sites/default/files/cruscotto_statistico_giornaliero_13-04-2018.pdf

${ }^{3}$ http://www.lemonde.fr/europe/article/2018/04/04/incident-frontalier-franco-italien-les-excuses-de-paris-a-rome_5280383_3214.html?xtmc=bardonecchia\&xtcr=1 and http://www.corriere.it/cronache/18_aprile_01/polizia-francese-bardonecchia-dogana-governo-ambasciatore-convocato-eae864fa-3521-11e8-8de8-ad207e8187ca.shtml

${ }^{4} \mathrm{https}: / / \mathrm{www}$. immigration.interieur.gouv.fr/Info-ressources/Etudes-et-statistiques/Statistiques/Essentiel-de-l-immigration/Chiffres-clefs

5 The data provided by the Ministry of the interior show an important and significative increasing of the asylum applications $(+105.8 \%$ in 2016 compared to 2015$)$ and of refugees $(+20.2 \%)$.

https://www.immigration.interieur.gouv.fr/content/download/103943/821424/file/EM-2017-1-les-titres-de-sejour-au-11-juillet-2017.pdf
} 
General Assembly, the Minister of the Interior Gérard Colomb declared that the number of foreigners in an irregular situation in France is estimated at "around 300,000 ", and pointed out that repatriation had increased "by $6.5 \%$ " in the last year ${ }^{6}$. Then, during an interview for the program "Questions politiques" ("France Inter"), in February 2018, he explained that if we were to compare January 2018 with January 2017, we could observe an increase of $+29 \%$ of repatriations: "What I want is that those whom we welcome in France can have a future in our country", he explained. "Last year, we had 100.000 applications for asylum, an increase of $+7 \%$ over the previous year, which itself was up 23\% compared to the previous year." 7

\section{Integration and inclusion strategies}

\subsection{Definitions}

"Assimilation, integration, insertion, inclusion", is the chronological order notions used in academic literature to characterize an excluded and marginal population that deviates from the dominant social norm. (Dubar 1992) Indeed, the political objective is often to incorporate, motivate, reintegrate these individuals through institutions, and sport contributes to these actions. (Lapeyronnie 1993) According to Avanzini, the strategy sometimes used relies on the elimination of differences in the name of the search for unity. (1994: 27) Robinson (1998: 118) suggested that 'integration' is a chaotic concept: a word used by many but understood differently by most'. Suggesting, further, that the concept is 'individualized, contested and contextual.' (ibid.)

Therefore, the terms "inclusion" and "integration" have been associated with very different kinds of populations "excluded" or "dis-integrated" because of some of their characteristics, deviance, stigma, forms of vulnerability or other features: aged, disabled and unemployed people, immigrants, people in a condition of socio-spatial or economic segregation, prisoners, and - depending on the situation and the perception of their normative-based deviance - also LGBTIQ people among others.

The European Commission defines "social inclusion" as a process enabling people at risk of poverty and social exclusion to benefit from the opportunities and resources needed to participate in economic and social life, enjoying a way of life considered "normal" in the society in which they live. ${ }^{8}$ Indeed, the concept of social inclusion is a European terminology, used to express the existing relationships between individuals and social systems, and was absorbed by the language of the French system and partly also of the Italian one, to design a set of public policies dedicated to social, economic, educational and cultural integration.

\footnotetext{
${ }^{6} \mathrm{http}: / / \mathrm{www}$. leparisien.fr/societe/environ-300-000-etrangers-sont-en-situation-irreguliere-en-france-annonce-gerard-collomb-08-11-2017-7381845.php

${ }^{7} \mathrm{https} / /$ /www.francetvinfo.fr/monde/europe/migrants/immigration-irreguliere-gerard-collomb-annonce-une-hausse-de-29-des-reconduites-a-la-frontiere-en-janvier_2605630.html

${ }^{8} \mathrm{http}: / /$ ec.europa.eu/social/main.jsp?catId=1059\&langId=en
} 
Thus, "social inclusion" is a major theme of the social policy of the European Union, which has been the subject of a paradigm shift since March 2000, illustrating the will to consider the phenomena of social exclusion in a different way. This change is expressed through a terminological evolution, since the policy of fighting against exclusion has since become the "social inclusion policy", marking the birth of the above-mentioned Lisbon European strategy.

The term "integration" could be used with widely differing meanings. Key domains of integration, for instance, are proposed by Ager and Strang (2008) as related to four overall themes: achievement and access across the sectors of employment, housing, education and health; assumptions and actions regarding citizenship and rights; processes of social connection among and between groups within the community; and structural barriers to such connection related to language, culture and the local environment.

According to William Gasparini (2012), if applied to the macro-context of sport, the term "integration" raises questions that are quite problematic. Rooted principally in a Durkheimian and Republican approach in France, the European Institutions (The council of Europe and the European Union) prefer the terms "insertion" or "cohesion through sport" to identify the phenomena that we are talking about.

In fact, the notions of "integration" and "inclusion" - considering also the fact that there are semantic nuances that make it difficult to compare the two concepts in Italian and French - don't correspond to any concrete experience, but they can frame sociological questions, even if they aren't directly operational in the research process. So we cannot study integration or inclusion as such, but we can analyse their various dimensions at a given moment, for example as practices generating social bonds and education, and sport is one of the dimensions or strategies through which these dimensions are provided. (Gasparini 2012)

\subsection{A problematic question}

The problem of inclusion/integration strategies, in Italy, is strictly linked to available material resources and, in general, to the territorial traditions of the different regions. These traditions affect the hosting process in terms of ability to integrate and possibility to find adapted infrastructures to overcome the unavoidable emergency period after the arrival of immigrants. As we will show subsequently, the Italian national regulation of the immigration process is basically centered on rules of limitation. The problem of welcoming policies is funded and regulated at a national level and implemented locally. As a matter of fact, there is not a standard model of integration. The standardized procedure stipulates that in a very first phase, the immigrants are hosted in so-called HotSpots, after being identified and/or registered. Then they can apply for "refugee" status (something that happens in most cases) within the protection system for asylum seekers and refugees, in different parts of the Italian territory. This system, based on the local action of a territorial government structure (Prefecture), provides 
the location for hosting and feeding the immigrants, mostly (90\%) by working with third sector organizations receiving a daily payment for every person they have under their charge.

Local communities are frequently dissatisfied with the assignation of these people who, usually, are waiting for they reply to their refugee application and are not entitled to be hired for regular jobs. So the result is that they hang around the hotels or apartments assigned to them.

Municipalities and third sector organizations - inconsistently - try to organize activities where these people could be suitably employed. For instance, some municipalities ask for volunteers to help with services like street cleaning, trying to create a form of socialization within local communities; this could be attempted using a range of different activities, organized or otherwise, in the field of cultural, social and educational integration.

These activities could be the services that allow the refugees to enter a legal, health, educational and social system, to learn the language with which to communicate with Italians, to gain some employment opportunities, to mix minors in school together with other minors of the area, to engage them in some leisure practices, for example sport or cultural activities. They also allow the resident population to know these people, to share festive occasions; daily life practices, maybe even conflicts, but mediated by the operators of the project.

As for France, the integration path - similar to the Italian one in terms of the hosting of the immigrants - is complicated by the fact that France, as we have seen, does not legally recognize communities (ethnical, cultural). This means that its policies can't target a specific community, unlike that which happens in Anglo-Saxon countries. The French model is based on the respect for Republican values, that are strictly secular: the laws about the wearing of religious symbols (2004) and the concealment of the face in public places (2010) are some examples. As for the integration process, it is based on the "Contrat d'Intégration Républicaine" (Republican Integration Act), created by the law of 7 March 2016 concerning the rights of foreigners. In July 2016 it replaced the "Reception and integration contract" which had been in force since 2007. Foreigners admitted for the first time to stay in France and wishing to settle there permanently must sign it, except in special cases. It includes civic and linguistic training and support tailored to the needs of newcomers to facilitate their rapid integration into society.

\section{Case studies}

To concretize our analysis, we will now present some case studies exemplifying the way sport and physical activities are used as means of social integration/inclusion in France and Italy. These examples do not intend to be representative: we chose them strategically in order to highlight some aspects that we believe are interesting and relevant to our argument. 


\subsection{Italy \\ 4.1.1 Contextual factors}

Based, mainly, over the few integration elements outlined above, the practice of integration through sport in Italy is a sort of fragmented patchwork.

The integration phenomenon has always been confronted by Italian lawmakers in a very hurried way. The first organic law about immigration dates back to the 90s (s.c. legge Martelli): it was the first attempt to regulate the phenomenon organically. The results were not efficient enough in terms of the regulation achieved: mechanism like the visa for work, the cut-off of the number of acceptances per year and the expulsions of illegal immigrants were only applied sporadically. As a result, the number of irregular immigrants increased. Ten years later $\left(1998^{9}\right.$ and $\left.2002^{10}\right)$ some new laws introduced a stricter regulation of immigration: Centres for identification and temporary detection were created, the duration of settlement visas was reduced, and compulsory identification by fingerprints was introduced. The situation changed after the Libyan war of 2011 and got even worse with the Syrian war: the increasing number of refugees, mixed with "standard" economic immigrants, led to an increasing number of deadly shipwrecks due to the increased number of clandestine sea crossings. The Italian Government at first and, after a long time, the EU, stated new rules for immigration policies with particular attention for life saving norms.

That being said, the problem of integration in the Italian national law is relatively absent. In general regional laws governed the normative definition of the process, with the side effect of being a little chaotic concerning one of the most important elements of the whole immigration process.

All the practices described here are based partly on third sector organization engagement and partly on public bodies ${ }^{11}$ and Ministry offices' actions.

The Italian Olympic Committee in 2016 published an interesting assortment of good practices among sport and integration (CONI 2016). In this collection we identified the three examples, which best fitted (our model?).

Preliminarily, as we will underline throughout this paper, the majority of these practices are based around the playing of football. The potential of football is widely recognised in literature (see, for instance, Giulianotti and Robertson 2007) and, overall, the globalisation of media system and this sport's representations therein mean that it has become a part of the public consciousness and even a form of pervading subculture for most of humanity in the 21 st century.

At the end, we face a curious phenomenon that shows us people struggling and escaping from war, underdevelopment and unemployment, but with a clear vision of the current myths in sports and, very often, provided with technological devices that could efficiently inform them about their passion for sport.

So, in the end, the most successful practices in Italy, overall in terms of participation, are based on football games or small football championships.

\footnotetext{
9 "Disciplina dell'immigrazione e norme sulla condizione dello straniero", Law of March the 6th, 1998, n. 40.

10 "Modifica alla normativa in materia di immigrazione e di asilo", Law of July the 30th, 2002, n. 189

${ }^{11}$ The Olympic Committee in Italy (CONI) is basically a public body financed with public resources.
} 


\subsubsection{Three case studies: "Mondiali antirazzisti", "Liberi cammi- nantes" and rugby in Alessandria}

One of the most successful events in Italy is the "Mondiali antirazzisti"12 (Anti-Racist World Championship). Organized in the province of Bologna (Emilia-Romagna region), they clearly represent a kind of game, in their intention, an amateur event in the strict sense, with a lot of communitarianism and little competitiveness. The event, that is staged annually, is able to bring together some 30,000: spectators, athletes (almost 4,000), friends and relatives, building up not only a sport event but a sort of giant multicultural festival where the average age of participants is between 18 and 25 .

During the event, seminars and debates are held; evening shows and even cooking workshops are run by participants and relatives not involved in the games. All in all, the event offers the opportunity to share positive representations of cultures that, thanks to the framework provided by the football games, are no longer alien and the migrants are perceived as being able to integrate themselves in the local community and return a positive representation of the Self as a person integrated in a given frame of values.

A local Roman sport club 'Liberi Nantes' represents a second "good practice". The association manages a football team, composed solely of refugees and asylum seekers, who are regularly involved in the local amateur championship. But the second, and the most interesting activity organized by this association, is the hiking activity, called "Liberi Camminantes" (a wordplay meaning "free to walk"). This activity is not as significant in terms of participation (about 50 refugees joined the activity in 2016) but represents a relevant experiment of "environment socialization". In their first four years of activity, participants walked for more than $2.000 \mathrm{~km}$ and participated in the World Walking Day, promoting the culture of exercise among the other refugees and representing, through their simple presence, a sort of normality in the day to day of the communities encountered during their walk.

The last example of sport socialization is held in Alessandria, in the Piemonte region, and concerns rugby. Here we have a pure positive coincidence that could be due to the fact that the rules of rugby are not that simple to figure out (contrary to football's) and generally the play is amazing, but neither easy to enjoy nor easy to practice, at least in Italy, where the representation of sport is strongly linked to the practice of football. None of the people involved in the project knew the egg-shaped ball. And it has been a really significant success when the team, $80 \%$ of whom are asylum seekers, was granted permission to participate in the national seniors championship (amateurs).

The results obtained were positive in enhancing sports and, broadly speaking, integration. The town was a little bit stunned to be represented on a national stage by such a particular team. And, overall, the athletes were aware of representing something and proud of it. The common roots of these forms of

\footnotetext{
${ }^{12}$ http://www.mondialiantirazzisti.org/new/
} 
relations are the same as the theory of the gift, well exemplified in Godbout \& Caillé in 1998 and, in general, it deals with the theory of "Generalized Exchange" presented by Lévi-Strauss. (1967)

\subsection{France}

\subsubsection{Contextual factors}

The Advice Law of 1984, known today as the Law of July 16, 1984, concerning the organization and promotion of physical and sporting activities, can probably be considered as being the first concrete reference to the use of sport as a means of education and integration. (Gasparini, Vieille-Marchiset 2008) It indicates that sport contributes to the renovation of the education system, the fight against disengagement at school and the reduction of social and cultural inequalities, constituting "an important factor of life balance, health and personal fulfilment."

As we can see on the French Ministry of Sports ${ }^{13}$ website, the Multiannual plan for fighting against poverty and for social inclusion ("Plan pluriannuel de lutte contre la pauvreté et pour l'inclusion sociale"), which was adopted at the Interministerial committee against exclusions ("Comité interministériel de lutte contre les exclusions") of January 21, 2013, incorporates a specific measure to facilitate "access to sports and recreation", part of an approach that aims more broadly to promote access to the rights of the most vulnerable populations and/or of those engaged in an integration process.

The multiannual plan for fighting against poverty and for social inclusion is structured around three main objectives: to reduce inequalities; to help and support insertion; to coordinate social action and to value its actors. We must consider the fact that both France and more generally the European countries entrust more and more missions of education through sport - traditionally taken on by school and physical education teachers - to the associative sports sector, as we have also seen in the Italian case studies.

Each of these axes is based on roadmaps, entrusted to the various Ministries, which are concerned. "Access to sports and recreation" is the subject of a specific measure aimed at defining a common strategy to support the development of territorial projects, integrating sports practices in support of vulnerable people.

By aiming to promote an offer of physical and sporting activities to vulnerable people or those engaged in an integration process, the ministry in charge of sports meets one of the priorities of social ministries: the fight against social inequalities by promoting physical and sports activities, a tool that promotes social bonding and "living together".

In this framework, we will highlight two "good practices", one built into the framework of the fight against poverty adopted by the French Government, the

\footnotetext{
${ }^{13} \mathrm{http} / / /$ www.sports.gouv.fr/pratiques-sportives/le-sport-pour-tous/Education-insertion-11073/article/Le-sport-facteu$\mathrm{r}$-d-inclusion-sociale
} 
other one more localized - and not only focusing on immigrants -, but which highlights some interesting critical aspects.

\subsubsection{Case studies: The DIPS, and Karate in a disadvantaged neigh- bourhood}

The DIPS (Dispositif d'Inclusion par le Sport) ${ }^{14}$ is a device constructed within the framework of the multi-year plan to fight against poverty and for social inclusion adopted by the French Government during the Interministerial Committee for fighting against exclusions held on January 21, 2013, which set out the need to promote access to sports and leisure for vulnerable families by integrating the support for people in situations of exclusion. The National Orientation Guidelines (Directives Nationales d'Orientation - DNO) of 2013 and 2014 , among others, have made it a priority to democratise access to sports, and to promote access to sports for vulnerable populations. Similarly, the Regional Director of Youth, Sports and Social Cohesion (Directrice Régionale de la Jeunesse, des Sports et de la Cohésion Sociale) of the Center-Val de Loire Region aims to "make sport a vector of social cohesion in the region, to support the development of physical activities and sports for all, and for all ages, by promoting the fight against unequal access to sports practices." 15

This project, carried out in collaboration with departmental and regional institutional partners and two equestrian centres in Cher, aimed at structuring an offer of physical and sporting activities for the people hosted in the reception structures throughout the region, to facilitate their integration into society and their access to healthcare.

In this context, this experimental project represented an opportunity to: get started or return to a condition of activity; to be able to build a personal project; to regain self-confidence and self-esteem; and to create social bonds. In the end, this experimentation should make it possible to integrate sports and physical activity practices into the overall support of vulnerable people.

According to the organisers, the results were quite positive and the territorial dynamic was evident: more than 500 sports sessions were organised; 53 social institutions were involved; 30 weekly slots were organised; nearly 600 residents practiced sports and physical activity; about ten sports educators were involved; more than 1,500 participations in sports sessions were registered. In terms of results, in order to measure the expected effects, a "follow-up booklet" providing information on the investment of each participant, their autonomy and their lifestyle, complete with a self-evaluation section was provided. In addition to this, an evaluation of the sessions carried out by the sports facilitators and a satisfaction survey was provided as well. According to the organizers and to some external observers, among whom was the sociologist François Le Yondre, the

\footnotetext{
14 "Device of Inclusion Through Sport". This part was elaborated starting from the data available here: http://centre-val-de-loire.drdjscs.gouv.fr/spip.php?article 493

${ }^{15}$ See again http://centre-val-de-loire.drdjscs.gouv.fr/spip.php?article493
} 
feedback was generally excellent, and the device was very successful. ${ }^{16}$

The second experience that we want to illustrate has recently been reported by Carine Guérandel (Guérandel 2017a, 2017b and 2017c), and relates to an experience of social work and intervention through Karate in a "problematic" French neighbourhood. Even if just like many other French research it is difficult to refer to the ethnicity and religion of the participants, and the author doesn't spend much on the description of these characteristics, we propose Guérandel's work because she highlights some critical and really specific aspects related to the integration process: the "normalisation" of some behaviours.

The semistate institution of social work that she surveyed through an ethnographic participatory observation hosted 45 teenagers (including five girls) aged 11 to 17 , identified by the school as "violent" and disengaged students. The leaders of the project declared an aim to "deal with relational difficulties", "social reintegration" and "autonomy" of young people, most of them from economically and socially disadvantaged families.

As in other sectors of social work that mobilize sport among the urban youth of these kind of "neighbourhoods", in line with the logic of control, pacification of territories but also of socialization and integration (Arnaud 1999; Falcoz, Koebel 2005; Guérandel 2016; Gasparini, Vieille-Marchiset 2008), the institution considers physical practices as delivering a set of transferable positive values and thus being likely to favour a return to "ordinary civil life", or inclusion in the social context. According to this perspective, martial arts would channel adolescent violence by allowing the expression of simplified, ritualized and regulated aggression and by organizing a form of peaceful confrontation with psychological benefits such as Self (re)insurance and (re)construction. (Guérandel, Julhe 2011)

Carine Guérandel focused her observation on the normalization of sexual behaviors of the young people involved. She concludes that the work undertaken by the institution can be understood from the point of view of the "new clothes of male domination". (De Singly 1993) The educators of the "martial arts" workshop consider this sport as an educational practice to increase men's respect for women and their skills, to be non-violent towards them, while remaining protective, strong and effective. In this context, women can also be competent and recognized as such to the extent that they don't question the attributes of femininity. (Mennesson 2005) The gender order is reconfigured in such a way as to complicate the models of femininity and masculinity and to simplify the hierarchies between the sexes.

It seems important to remember that the actors of these interventions are never passive with respect to the processes of socialization/integration aimed at their transformation. Consciously or unconsciously, they can adopt attitudes of resistance and learn to play the game of the institution without their sexual dispositions being significantly modified. These "strategies" can be seen as forms of diversion from the meanings or heterodox appropriations of the dominant order. We

${ }^{16}$ http://centre-val-de-loire.drdjscs.gouv.fr/sites/centre-val-de-loire.drdjscs.gouv.fr/IMG/pdf/Ufolep_18_p24-26_repor tage_Dips-2.pdf 
shouldn't neglect these phenomena in the analysis of the effects of the institutional socialization of gender normalisation, both in the case of Carine Guérandel's observation, and in the more general framework of these actions of intervention.

\section{Crossing the experiences \\ 5.1. What makes the difference}

To simplify the differences between Italy and France as regards the issue of integration/inclusion through sports, we can identify three characterizing macro-dimensions.

The first one is strictly disciplinary. The evaluation of intervention strategies is also strongly linked to the development of a set of mature scientific disciplines, which allow us to deconstruct and question them. Unfortunately, sociology of sport and the macro-area of sociology of social intervention are not well developed in Italy, compared to France. Consequently, there is not even a politically and scientifically mature critical approach capable of developing a coherent discourse, except through the lens of disciplines that are not focused on the topic of social integration/inclusion, such as gender studies. On the other hand, in France we have significant barriers too. The difficulty or impossibility of collecting data about the ethnic/cultural origin of people limits the range of action at all levels: intervention, research, and criticism.

As for what concerns the second macro-dimension, in France there is long-standing immigration rooted in the country's colonial traditions, in opposition to Italy which has historically experienced immigration fluxes that were mainly internal (from South to North, and from rural to urban areas), and only in recent decades, with the collapse of the Soviet system and the North African and Middle Eastern crises did the country start to experience migratory flows, coming from outside.

The third dimension mainly concerns the topic of sports: the French collective imagination, especially as regards "media-sport" (Wenner 1998), is strongly multicultural, and according to many scholars, it has been strongly influenced by the exploits of the French national football team in the 1990s. In Italy, the majority of society doesn't seem to be aware of the potential of sport as a mean of integration: only recently, with a law called 'the sport citizenship' did some element linked sport and immigrants integration broke-up the wall of indifference within Italian society. From 20 January 2016 this law has allowed foreign minors to be registered within Italian sports federations. The law recognizes the principle of ius soli applied to sport club registration and applies to all children who regularly reside in the Italian territory "at least from age 11 onwards": they can expect to enrol in the federations "with the same procedures required for Italian citizens to become members." This was a significant moment but with less substantial impact on the generality of the phenomenon in terms of integration and awareness. 
These three dimensions partially explain the main differences between the use of sport as a means of social integration/inclusion. These differences manifest in a more "patchworked" approach in Italy, and in a more mature and reflexive manner in France.

\subsection{Comprehension}

When we get into the heart of the discussion, in response to the proclaimed fragmentation of national communities in many European countries, sport has often been presented as a unifying force or at least a model of integration for immigrant populations and for urban youths: this is the case of France, and this seems to be the path that Italy is partly following (Arnaud 1999; Gasparini 2005; Gasparini, Cometti 2010; Gasparini, Talleu 2010; Zolletto 2010; Gasparini 2012). Particularly preeminent in media and in political and public discourses, the topic of the integration of immigrant populations and - in the case of France - of young French people of Maghrebin origin through sport is perhaps a little reductive.

As for France, the mediatisation of high-level sport has certainly given substance to this belief, and this partly explains the fact that it developed earlier than in Italy. When the French football team won the World Cup in 1998 and the European Championship in 2000, many journalists highlighted the French football team as representative of a century of immigration. After the victory of the "blackblanc-beur" (Black-White-Coloured) French team, the adviser of the Minister of the Interior of the time declared that Zidane did more though his dribbles and his feints than many years of integration policy. The athletes of foreign (immigrant) origin, or more generally those coming from the most disadvantaged areas of the population, and who have succeeded through sport, appear as new media figures who gradually emerged from the end of the 1980s. This aspect helped to foster the idea (be it real or not) that France, through sports, throughout the twentieth century, naturally integrated people coming during different waves of immigration (Gasparini 2005). The examples of Zidane, Djorkaeff, Anelka, Desailly, Thuram and more recent ones suggest that sport, better than economics or politics, can function as a social boost for young people with of immigrant background. The fact that sport allows socially disadvantaged youth to find some kind of social recognition is a reality, as for some young people with specific physical abilities it can be a real mean of social promotion both in the in-group and in the out-group: they can find in high-level sport a space that recognizes their competences and that takes advantage of dispositions, qualities and practical knowledge valued in disadvantaged areas. But as Patrick Mignon states, there is an important gap between reality and utopia: the reality of competition and the cult of victory come to oppose the utopic values of integration, so it would be risky to say that sport allows easy integration. (Mignon 2000)

According to Gasparini (2012), there is some kind of social and symbolic recognition of success, based on figures of success, which is however the coun- 
terpoint for some significant racist manifestations which still happen in the stadiums and on the field, and that players of foreign origin can very often have their differences highlighted, both in France ${ }^{17}$ and in Italy. ${ }^{18}$ Moreover, William Gasparini - in line with Mignon's critiques - stresses the fact that if the visibility of some football players contributes to the myth of social salvation through sport, it also obscures the reality of social inequality and the discriminatory conditions in which many young people coming from immigration live. We must therefore beware of the mythical dimension of the representation of an integrative sport: it also leads to an underestimation of the logic of socio-spatial and economic segregation, stigmatization and ghettoization that are also present in the world of sport. (Gasparini, Cometti 2010; Gasparini, Talleu 2010)

This myth comes directly from what might be called the "sports ideology", promoted by the founding fathers of modern sport, and explored by some sociologists who were making the very first sociological approaches applied to sport: if on the one side Norbert Elias and Eric Dunning (1986) saw in sports an element of the process of civilization of manners, helping to control violence by replacing it with symbolic and peaceful confrontations, on the other - this critical perspective can help us to stress the critical aspect of sport integration Pierre Bourdieu (1994) notes that the regulated confrontation of modern sports allows the expression of bourgeois values such as fair play and self-government, and as such it brings some kind of domination and reproduction of these values, that is in someway in line with Carine Guérandel's observations.

\section{Concluding remarks}

To conclude, in Europe, knowledge of the social effects of sports - at least in the countries in which the motor sciences are present and the sociology of sports and physical activities is more advanced - are highly developed. When they are applied or configured as social policies for the integration of migrants and refugees, they tend to be only interventions on a material level, neglecting the cultural and religious aspects in an unjustified manner. In the French case, in particular, this gap is due to the difficulty of dealing with the issue of religiousness, in a pervasive "laicite" which - in the final analysis - prevents the implementation of policies aimed at - and adapted to - particular ethnic and religious groups.

Furthermore, if on the one hand the forms of domination proposed by Pierre Bourdieu emerge quite clearly especially in the analyses developed in the French territory, starting from a critical approach, on the other it is clear that the issues of the creation of the social bond and the sharing of social capital are fundamental. The debate sees on the one hand a tendency towards social integration

\footnotetext{
${ }^{17}$ As in the case of the Italian football player Mario Balotelli during the match of the french "Ligue" Bastia-Nice: http:// www.lemonde.fr/ligue-1/article/2017/01/22/ligue-1-la-lfp-condamne-les-auteurs-d-insultes-racistes-lors-de-bastia-nice_5066836_1616940.html?xtmc=racisme_football\&xtcr=37

${ }^{18}$ As in the case of the French football player Blaise Matuidi (Juvenus), during the match against Cagliari: http:// www.corriere.it/sport/18_gennaio_07/matuidi-facebook-ho-assistito-scene-razzismo-contro-me-la-partita-il-cagliari-deea94ba-f387-11e7-aa70-8e209e058724.shtml
} 
still based on an approach that is perhaps a little naïve (Italy), and on the other hand a tendency to question these mechanisms, which can sometimes manifest themselves as forms of assimilative domination and/or be counterproductive (France). This does not mean that the actions carried out in Italy are more (or less) effective and efficient than the French ones. We only state that for the reasons outlined above, the actions taken and the debate around them, both at the public/political and at the research level, are currently in two different historical and disciplinary phases. All these actions, we could state, could/must be implemented in a holistic framework: as recently stated by Mark Doidge (2018), when chronicling the practise of football in the "Jungle de Calais", institutional support and partnerships are vital in supporting these kind of actions. Thus, a holistic approach has to be utilised, based on a network of institutional and community partnerships, crucial to the success and sustenance of these types of projects. Similarly, a European framework, aiming to overcome unjustified national differences and to guarantee a correct balance between the aspiration to defend citizens rights to welfare and to providing an effective integration of immigrants at the end of a long migratory chain is important too.

\section{REFERENCES}

Alastair, Ager and Alison Strang. 2008. "Understanding Integration: A Conceptual Framework.” Journal of Refugee Studies 21: 166-191. DOI: 10.1093/jrs/fen016

Andrieu, Gilbert. 2009. Sport et spiritualité. Paris: L'Harmattan.

Arnaud, Lionel. 1999. Politiques sportives et minorités ethniques. Paris: L'Harmattan.

Avanzini, Giuseppe. 1994. "Insertion, intégration, assimilation.” Pp. 26-6 in Broyer, Gérard (dir.) Gèmes entretiens du centre Jacques Cartier. Lyon: Bulletin de liaison du CNDT.

Baquet, Maurice.1947, 1ère éd. 1942. Education Sportive. Initiation et Entraînement. Paris; Montréal: l'Harmattan.

Bausinger, Hermann. 2006. Sportkultur. Tubingen: Attempto.

Bergamaschi, Alessandro. 2013. "Giù le mani dal mio amico. Considerazioni sul ruolo delle amicizie inter-gruppo negli atteggiamenti dei giovani francesi e italiani nei confronti dell'immigrazione." Autonomie locali e servizi sociali 2: 265-278. DOI: $10.1447 / 75373$

Bourdieu, Pierre. 1994. Raisons pratiques. Paris: Seuil.

Brohm, Jean-Marie. 2006. La tyrannie sportive. Théorie critique d'un opium du peuple. Paris: Beauchesne.

Coakley, Jay. 2011. "Youth sports: What counts as "positive development?" Journal of sport and social issues 35(3): 306-324. DOI: 10.1177/0193723511417311

Commission of the European Communities. 2007. White paper on sport.

CONI, Sport e integrazione: La vittoria più bella. Le buone pratiche. 2016. Roma: Italian Olympic Committee editions.

De Singly, François. 1993. "Les habits neufs de la domination masculine." Esprit 196: 54-11.

Doidge, Mark. 2018. "Refugees united. The role of activism and football is supporting refugees." Pp. 2336 in Transforming sport: knowledges, practices and structures, edited by T. Carter, D. Burdsey and M. Doidge. Abingdon: Routledge. 
Dubar, Claude. 1992. La socialisation. Construction des identités sociales et professionnelles. Paris: Aramand Colin.

Elias, Norbert and Elias Dunning. 1986. Quest for excitement: sport and leisure in the civilising process. Dublin: University College Dublin Press.

Falcoz, Marc and Michel Koebel. dir. 2005. Intégration par le sport: représentations et réalités. Paris: L'Harmattan.

Ferrero Camoletto, Raffaella. 2005. Oltre il limite. Il corpo tra sport estremi e fitness. Bologna: il Mulino.

Gasparini, William. 2004. "Les contradictions de l'intégration par le sport.” Pp. 103-108 in Actes du colloque international "Intégration par le sport: état des recherches», Salé (Maroc), 25 mars 2003 edited by M.Koebel, Universités de Reims Champagne Ardenne, de Besançon et de Lille 2, Institut Royal de Formation des Cadres de Salé, Reims : UFR STAPS (URCA).

Gasparini, William. 2005. "Les contradictions de l'intégration par le sport." Pp. 243-7 in Intégration par le sport : représentations et réalités edited by M. Falcoz, M. Koebel. Paris : L’Harmattan.

Gasparini, William and Aurélie Cometti. eds. 2010. Sport facing the test of cultural diversity. Integration and intercultural dialogue in Europe. Strasbourg: Council of Europe Publishing.

Gasparini, William and Clotilde Talleu. eds. 2010. Sport and Discrimination in Europe. Strasbourg: Council of Europe Publishing.

Gasparini, William and Gilles Vieille-Marchiset. 2008. Le sport dans les quartiers. Pratiques sociales et politiques publiques. Paris: PUF.

Gasparini, William. 2012. "Penser l'intégration et l'éducation par le sport en France: réflexions sur les catégories d'analyse sociale et politique.” Movement \& Sport Sciences 4(78): 39-44. DOI: 10.3917/ sm.078.0039

Ghildiyal, Rakesh. 2015. "Role of sports in the development of an individual and role of psychology in sports.” Mens Sana Monogr 13: 165-170. DOI: 10.4103/0973-1229.153335

Giulianotti, Richard and Roland Robertson. 2007. "Recovering the social: globalization,

football and transnationalism." Global Networks 7 (2): 166-186. DOI: 10.1111/j.14710374.2007.00163.x

Godbout, Jacques and Alain Caille. 1998. World of the Gift. McGill-Queen's Press-MQUP.

Guerandel, Carine and Éric Marlière. eds. 2017a. Filles et garçons des cités d'aujourd'hui. Lille: Presses Universitaires du Septentrion.

Guerandel, Carine. 2017b. "Une nouvelle catégorie des politiques d' 'intégration par le sport': les 'filles des cités." Sciences sociales et sport 1(10): 79-111. DOI: 10.3917/rsss.010.0079

Guerandel, Carine. 2017c. "Sport, genre et travail social: une socialisation de normalisation des comportements sexués.” Pp. 75-21 in Sport, sexe, genre: représentations et narrations edited by A. Porrovecchio. Paris: L'Harmattan.

Guérandel, Carine and Samuel Julhe. 2011. "Des adolescents travaillés au corps. L'usage des activités physiques de combat dans un Institut Thérapeutique Éducatif et Pédagogique.” Pp. 237-21 in Education, sports de combat et arts martiaux edited by J-F. Loudcher, J-N. Renaud. Grenoble: PUG.

Kristine Höglund and Ralph Sundberg. 2008. "Reconciliation through Sports? The case of South Africa." Third World Quarterly, 29(4): 805-818, DOI: 10.1080/01436590802052920

Javeau, Claude. 2015. Je hais le football, Lormont: Le Bord de l'eau.

Lapeyronnie, Didier. 1993. “De l'intégration à la ségrégation.” Pp.97-115 in Ville, exclusion et citoyenneté edited by J. Roman. Paris: Esprit.

Le Breton, David. 2003. "Activités physiques et sportives et intégration: aspects anthropologiques.” Em- 
pan 3(51): 58-64. DOI: 10.3917/empa.051.0058

Lévi-Strauss, Claude. 1967. Les Structures élémentaires de la parenté. Paris: Mouton.

Mennesson, Christine. 2005. Être une femme dans le monde des hommes. Paris: L'Harmattan.

Mignon, Patrick. 2000. "Sport, insertion, intégration." Homme et migrations 1226: 15-26. DOI: 10.3406/ homig.2000.3540

Moussa, Kinda. 2013. Pratiques et politiques sportives dans les quartiers sensibles: une approche monographique aux 3 Cités à Poitiers. Côte d'Opale: Université du Littoral.

Robinson, Vincent. 1998. "Defining and Measuring Successful Refugee Integration”, Proceedings of ECRE International Conference on Integration of Refugees in Europe, Antwerp, November 1998. Brussels: ECRE.

Vinnai, Gerhard. 2007. "Eigentore. Zur ideologischen Funktion des Fußballsports." Psychosozial 30(110): 99-115.

Wenner, Laurence. ed. 1998. Mediasport. New York: Routledge.

Zoletto, Davide. 2010. Il gioco duro dell'integrazione: l'intercultura sui campi da gioco. Milano: Raffaello Cortina ed. 